\title{
Evaluation of Forest Preservation in Cambodian Rural Villages
}

\author{
Kaoru Ishiguro ${ }^{1}$ \\ ${ }^{1}$ Graduate School of Economics, Kobe University, Hyogo, Japan \\ Correspondence: Kaoru Ishiguro, Graduate School of Economics, 2-1 Rokkodai, Nada-ku, Kobe, Hyogo, \\ 657-8501, Japan. Tel: 81-78803-6835. E-mail: ishiguro@econ.kobe-u.ac.jp \\ Received: November 15, 2018 \\ doi:10.5539/jsd.v12n1p27 \\ Accepted: December 15, $2018 \quad$ Online Published: January 31, 2019 \\ URL: https://doi.org/10.5539/jsd.v12n1p27
}

\begin{abstract}
Forest preservation in Cambodian rural villages is empirically investigated using contingent valuation method. The article's findings are as follows. First, the participation of local residents in forest preservation differs according to the nature of the relevant activity (i.e., whether it is tree planting, forestry management, or refraining from logging). Second, participation in forest preservation differs according to socioeconomic attributes such as gender, age, number of household members, household income, education level, occupation, and purpose of forest use. Third, unlike in previous studies, it was found that education level and household income are not necessarily significant factors in participation in forest preservation.
\end{abstract}

Keywords: Cambodian rural villages, forest preservation, refraining from logging, CVM, WTW

\section{Introduction}

In line with the United Nations' Millennium Development Goals, the Cambodian government produced its own Cambodia Millennium Development Goals in 2001, one of which was "ensure environmental sustainability" (Ministry of Planning, Cambodia, 2003). Among the targets toward achieving this goal is "to reverse the loss of forestry resources," and a goal was set of $60 \%$ of total land area to be reforested by 2015 . According to the Cambodian government, $22 \%$, or 2.85 million hectares, of forested land was lost between 1990 and 2000 (Ministry of Planning, Cambodia, 2014). The rate of forest reduction in the period from 2005 to 2010 was 1.2\%. As of 2014, forest accounted for 48\% (8.66 million hectares) of total land area (18.1 million hectares) in Cambodia (Open Development Cambodia, 2016).

The aim of this article is to empirically investigate forest preservation in Cambodian rural villages using the contingent valuation method (CVM). The data used in the analysis were collected using interviews carried out by the author in September 2016. Contingent forest preservation projects were simulated for seven villages in Siem Reap Province in Cambodia, and local residents were "invited" to participate in these projects. The interview questionnaire has a double-bounded dichotomous choice and includes the following three main sets of questions: 1) number of days of participation in voluntary forest preservation work (defined as "tree-planting or forest management"); 2) if participating in such voluntary work, whether it would be specifically in tree-planting or in forest management; 3 ) number of days refrained from logging. A total of 233 people was interviewed, and the data were processed using logit analysis.

The main findings of this article are as follows. First, participation in forest preservation activity differs according to the nature of the activity (i.e., whether it is tree-planting, forest management, or refraining from logging). Almost $80 \%$ of local residents say they would participate in forest preservation (when defined as "tree-planting or forest management"), but the figure for participation in forest management specifically falls to just over $40 \%$. The participation rate for refraining from logging is just under $60 \%$. Second, participation in tree-planting, forest management, and refraining from logging differs according to socioeconomic attributes such as gender, age, number of members in household, household income, education level, occupation, and purpose of forest use. Third, household income and educational level are not necessarily significant factors in participation in forest preservation. Increase in household income is associated with a negative attitude to refraining from logging. In addition, a rise in education level does not stimulate participation in forest preservation activity.

The significance of this article lies in the fact that it obtained findings that differ from the results of previous studies. First, in general, the higher the household income, the more likely the participation in forest preservation. However, in the analysis in this article, household income is not a significant factor overall. Rather, with regard 
to refraining from logging, the higher the household income, the lower the participation. Second, many studies indicate that those with a high education level will understand environmental problems and are likely to participate in forest preservation. However, in the analysis in this article, level of education is a significant variable only for the "tree-planting or forest management" category. Furthermore, participation in forest preservation is lower for those who graduated from primary school than for those who did not finish primary school.

The structure of this article is as follows. Section 2 contains a review of previous research relating to forest preservation that used CVM. Section 3 outlines the interview process and describes the analytical method, with results presented in Section 4. In Section 5, the results are discussed, while Section 6 summarizes the article's conclusions.

\section{Literature Review}

The following section presents a discussion of previous forest preservation studies using CVM, from the viewpoint of household income, education level, and understanding of environmental protection.

First, studies by Yoeu et al. (2010), Muranaka and Terawaki (2005), Linde-Rahr (2008), and Amiri et al. (2015) show household income to be a significant positive variable for participation in forest preservation. In contrast, Brugnaro (2010) reports household income as a significant negative variable.

Yoeu et al. (2010) measured farmers' willingness to pay (WTP) with regard to the flooded forests in Cambodia's Tonlé Sap Lake region using single-bounded dichotomous-format CVM. The dependent variable was the WTP of farmers participating in the preservation of the flooded forest, and the independent variables were gender, age, number of household members, household income, level of education, distance of residence from the flooded forest, and participation in flooded forest preservation planning. There were 157 participants, and multiple regression analysis of the results showed high WTP was associated with 1) high household income, 2) advanced age, and 3) participation in the planning of flooded forest preservation.

Muranaka and Terawaki (2005) investigated the number of days that local Japanese residents were willing to volunteer to manage community forests (satoyama), using an open-ended CVM. The dependent variable was the maximum number of days per annum that the respondent was able to participate in volunteering activities in community forest management. The independent variables included gender, age, occupation, household income, proximity to the forest, and knowledge of the forest. There were 142 participants in all, and negative binomial regression analysis of results indicated that a high number of volunteering days is associated with 1) high household income, 2) women, 3) general knowledge relating to community forests, and 4) frequent visits to the community forest.

Linde-Rahr (2008) investigated the difference in local residents' WTP for differing ownership rights when ownership of state-owned forests in Vietnam was transferred to the private sector. A total of 300 people was questioned using an open-ended CVM, and Tobit analysis of the results indicated that high household income was associated with high WTP, whether the forests became completely privately owned or only usage rights were transferred. Education level was a significant positive variable only when usage rights were transferred.

Amiri et al. (2015) conducted a study using a double-bounded questionnaire of local residents' WTP and willingness to accept compensation (WTA) regarding forest preservation (in particular regarding medicinal herb preservation) in Iran. The independent variables included gender, age, marital status, number of household members, household income, level of education, and understanding of environmental issues. Logit analysis of the responses from 300 participants indicated that high WTP was associated with 1) high household income, 2) high education level, and 3) a low number of household members.

On the other hand, Brugnaro (2010) reported that household income was a significant negative variable. He investigated local residents' WTP to restore the forests of the Corumbatai river basin in Brazil. Logit analysis of the results of 930 street-intercept interviews indicated that low WTP was associated with 1) high household income and 2) advanced age. This result may reflect disillusion with the Brazilian government's past strategies.

Second, level of education was a significant variable in studies by Luangmany et al. (2009), Linde-Rahr (2008), and Amiri et al. (2015). Luangmany et al. (2009) investigated WTP for forest preservation in national parks in Laos, using a five-level bidding game CVM. The amount payable for forest preservation was gradually increased from the base amount to find the highest sum that received an affirmative answer from at least $50 \%$ of respondents. The independent variables were gender, age, household income, education level, and distance of residence from the park. Logit analysis of the answers from 400 respondents showed that high WTP was associated with 1) a high level of education and 2) women. The aforementioned studies by Linde-Rahr (2008) 
and Amiri et al. (2015) also showed that high WTP is associated with a high level of education.

Third, studies by Stone et al. (2008), Muranaka and Terawaki (2005), and Yoeu et al. (2010) showed understanding of environmental protection to be a significant variable. Stone et al. (2008) investigated participation of local residents in mangrove forest restoration on India's western coast according to attribute categories such as male or female member of fishing community and rice farmer. Independent variables included age, number of household members, level of education, knowledge of coastal preservation and erosion, and purpose and value of use of the mangrove forest. Logit analysis of results from 287 participants showed that the factors driving participation differed according to attribute category. Each group has its own interest with 1) men from fishing communities focusing on preservation of the coastal area, 2) women from fishing communities focusing on coastal erosion, and 3) rice farmers focusing on birds that eat pests. High interest in these topics was associated with high relevant WTP and WTW. As previously mentioned, Yoeu et al. (2010) and Muranaka and Terawaki (2005) also found that understanding of environmental protection and the local area was associated with high WTP and WTW.

\section{Method}

\subsection{Area Surveyed}

The surveyed area covers seven rural villages in Chi Kraeng District in Siem Reap Province. This is a region where rice is grown using typical Cambodian rain-fed agricultural methods. It is a poor area where around $70 \%$ of households are below the rural poverty line $(3,503$ riel per person per day, 1 UDS $=4,029$ riel) set by the Cambodian government. Reduction in forested land is even more severe in Siem Reap Province than in the country as a whole. Forested land in the province fell by around 219,000 hectares between 2000 and 2014, the seventh-worse decline of any province (Open Development Cambodia, 2015).

The Cambodian government produced its own Cambodia Millennium Development Goals in line with the United Nations' Millennium Development Goals, formulating indicators relating to forest preservation. Of interest here is Overall Target 13 ("integrate the principles of sustainable development into country policies and program and reverse the loss of environmental resources"), which is mentioned in the seventh Cambodia Millennium Development Goal ("ensure environmental sustainability"). Overall Target 13 is broken down into nine indicators. Among these, three relate to forest preservation: 1) the proportion of total land area that is forested; 2) the number of rangers in protected areas and forest-protected areas; and 3) reliance on fuel wood.

Regarding indicator 1) (the proportion of total land area that is forested), the proportion of Cambodia's total land area (around 18.1 million hectares) that is forested (around 8.66 million hectares), at $48 \%$ in 2014, was below the 2015 target of $60 \%$. The proportion has fallen each year, with relevant figures since the 1970 s being $72.1 \%$ (1973), 68.0\% (1989), 66.7\% (2000), 63.1\% (2004), 60.2\% (2009), and 47.7\% (2014) (Open Development Cambodia, 2016).

Regarding indicator 2) (the number of rangers in protected areas and forest-protected areas), as of 2013, there are 23 protected areas (PAs), where the aim is to protect and maintain the ecosystem and natural and cultural resources (Ministry of Environment, Cambodia, 2003), with a total area of around 3.1 million hectares. Forest-protected areas are set up within the protected areas, with the particular aim of protecting the ecosystem. (Note 1) The targets for the number of rangers in 2015 were 1,200 for protected areas and 500 for forest-protected areas. The number of rangers in protected areas fell from 600 in 2001 to 480 in 2010 but increased to 910 in 2012 (Ministry of Planning, Cambodia, 2014). The number of rangers in forest-protected areas declined from 500 in 2001 to 315 in 2012.

Regarding indicator 3) (reliance on fuel wood), in 2005, 84.8\% of all households in Cambodia relied on fuel wood for cooking, with the figures for urban and rural households being $43.6 \%$ and $91.3 \%$, respectively. In 2010 , these numbers fell to $79.5 \%$ for all households in Cambodia, $27.6 \%$ for urban households, and $90.1 \%$ for rural households (Ministry of Planning, Cambodia, 2011, 2014). However, achievement of the 2015 target of 52\% for all Cambodian households is not close to being achieved. Reliance has fallen for urban households but remains high for rural households. (Note 2)

\subsection{Data}

Methods of evaluating forest preservation can be classified as "revealed preference" and "stated preference." CVM is a "stated preference" method, whereby the value placed on forest preservation is measured using a questionnaire. With this valuation method, the contingent case of the forest being preserved is proposed and the value placed on this preservation is measured using direct questioning of beneficiaries.

The value of the benefit in CVM is measured using the amount the respondent is willing to pay (WTP) and the 
number of days of voluntary work in which the respondent is willing to work (WTW). In developing countries, in some cases, even when respondents have a positive attitude to forest preservation, their incomes are severely restricted, and they are unable to pay a monetary sum. (Note 3) In addition, when forest preservation relies on volunteers, cost is not measured in units of currency but in units of labor, and it is therefore also necessary to measure the benefit in units of labor. In this article, WTW in forest preservation on the part of residents in Cambodian rural villages is used as a valuation measure.

In the survey, a contingent forest preservation project was proposed, and the survey participants were "invited" to participate in that project. The questions have a double-bounded dichotomous choice, and there are three main sets of questions: 1) the number of days of participation in voluntary labor for forest preservation (defined as "tree-planting or forest management"); 2) whether, when participating in such voluntary labor, the respondent is willing to participate specifically in tree-planting activities or in forest management; and 3) the number of days refraining from logging.

The first set of questions asked for the maximum number of days per annum the local resident felt able to participate in forest preservation. The level-one question asked about willingness to participate in forest preservation once a year. When the respondent was willing to participate on this basis, a level-two question was posed about participation in forest preservation twice a year. Where the respondent was not willing to participate once a year, a level-two question about participation once every two years was asked.

The second set of questions asked whether, when the respondent had agreed in the first set of questions to participation in voluntary labor at least once every two years, the respondent was specifically willing to participate in either tree-planting or forest management, or in both.

The third set of questions asked, using a double-bounded dichotomous choice, about the number of days per month the local resident felt able to refrain from logging. The level-one question asked about refraining from logging for two days a month. When the respondent agreed to participation on this basis, a level-two question was asked about refraining three days a month. When the respondent gave a negative response to the level-one question, the level-two question was asked about refraining once a month.

The survey was carried out during individual face-to-face interviews in September 2016. Of the 233 people who were interviewed, 74 were men and 159 women. The average age was 42.3 years, and the average household income US $\$ 49.2$ per month. The average number of household members was 4.9 people, with the average number of children being 2.9, and the average number of household members working away from home being 0.3. Looking at education level, $80.1 \%$ of respondents did not finish primary school. With regard to occupation (multiple answers allowed), $96.6 \%$ worked in agriculture and $76.4 \%$ in forestry. Reliance on forestry was high in Village TP (100\%) and Village KS (93.3\%) and lowest in Village DS (34.4\%). The most common purpose of use of the forest (multiple answers allowed) was timber/fuel such as fuel wood at $99.1 \%$. (Note 4)

Table 1 shows intention to participate in all forest preservation activities (tree planting, forest management, refraining from logging). This is participating twice a year in "forest preservation" (defined as "tree planting or forest management") or in forest management and refraining from logging three days a month. The rate of participation in "tree planting or forest management" is $77.7 \%$, or 181 people, $43.8 \%$, or 102 people in forest management, and $56.7 \%$, or 132 people in refraining from logging. Almost $80 \%$ of respondents indicated that they would participate in "tree planting or forest management," but the rate of participation in forest management fell to just over $40 \%$.

Table 1. Participation in forest preservation activities

\begin{tabular}{cccccccc}
\hline & \multicolumn{3}{c}{ Forest Preservation } & \multicolumn{2}{c}{ Forest Management } & \multicolumn{2}{c}{ Refraining from Logging } \\
Village & Obs. & Number & Rate (\%) & Number & Rate (\%) & Number & Rate (\%) \\
\hline OL & 30 & 25 & 83.3 & 12 & 40.0 & 19 & 63.3 \\
CH & 53 & 38 & 71.7 & 19 & 35.8 & 19 & 35.8 \\
DS & 32 & 27 & 84.4 & 19 & 59.4 & 27 & 84.4 \\
KS & 60 & 50 & 83.3 & 26 & 43.3 & 37 & 61.7 \\
TV & 20 & 12 & 60.0 & 6 & 30.0 & 12 & 60.0 \\
Ro & 33 & 25 & 75.8 & 18 & 54.5 & 14 & 42.4 \\
TP & 8 & 4 & 50.0 & 2 & 25.0 & 4 & 50.0 \\
Total & 233 & 181 & 77.7 & 102 & 43.8 & 132 & 56.7 \\
\hline
\end{tabular}


There were differences between the various villages with regard to participation in all forest preservation activities. Village DS had the highest participation rate for tree planting, forest management, and refraining from logging. The participation rate for "tree planting or forest management" was highest in Village DS, at 84.4\%, and lowest in Village TP, at 50.0\%. The rate of participation in forest management was highest in Village DS, at $59.4 \%$, and lowest in Village TP, at $25.0 \%$. The rate of refraining from logging was highest in Village DS, at $84.4 \%$, and lowest in Village $\mathrm{CH}$, at $35.8 \%$.

\subsection{Variables and Basic Statistics}

Table 2 shows the variables used in the analysis and their definition. The dependent variables refer to the likelihood of participating in forest preservation. This covers three variables: 1) the likelihood of participating in "tree planting or forest management" for two days each year; 2) where the respondent will participate in "tree planting or forest management" at least one day every two years, the likelihood of participating specifically in forest management; and 3) the likelihood of participating in refraining from logging three days each month. The independent variables comprise 1) socioeconomic attributes of the individual respondents (gender, age, household income, number of household members, number of children, number of household members working away from home, level of education, occupation, purpose of use of forest) and 2) attributes of the rural village concerned (each of the seven villages distinguished by a dummy variable).

Table 2. Explanation of variables

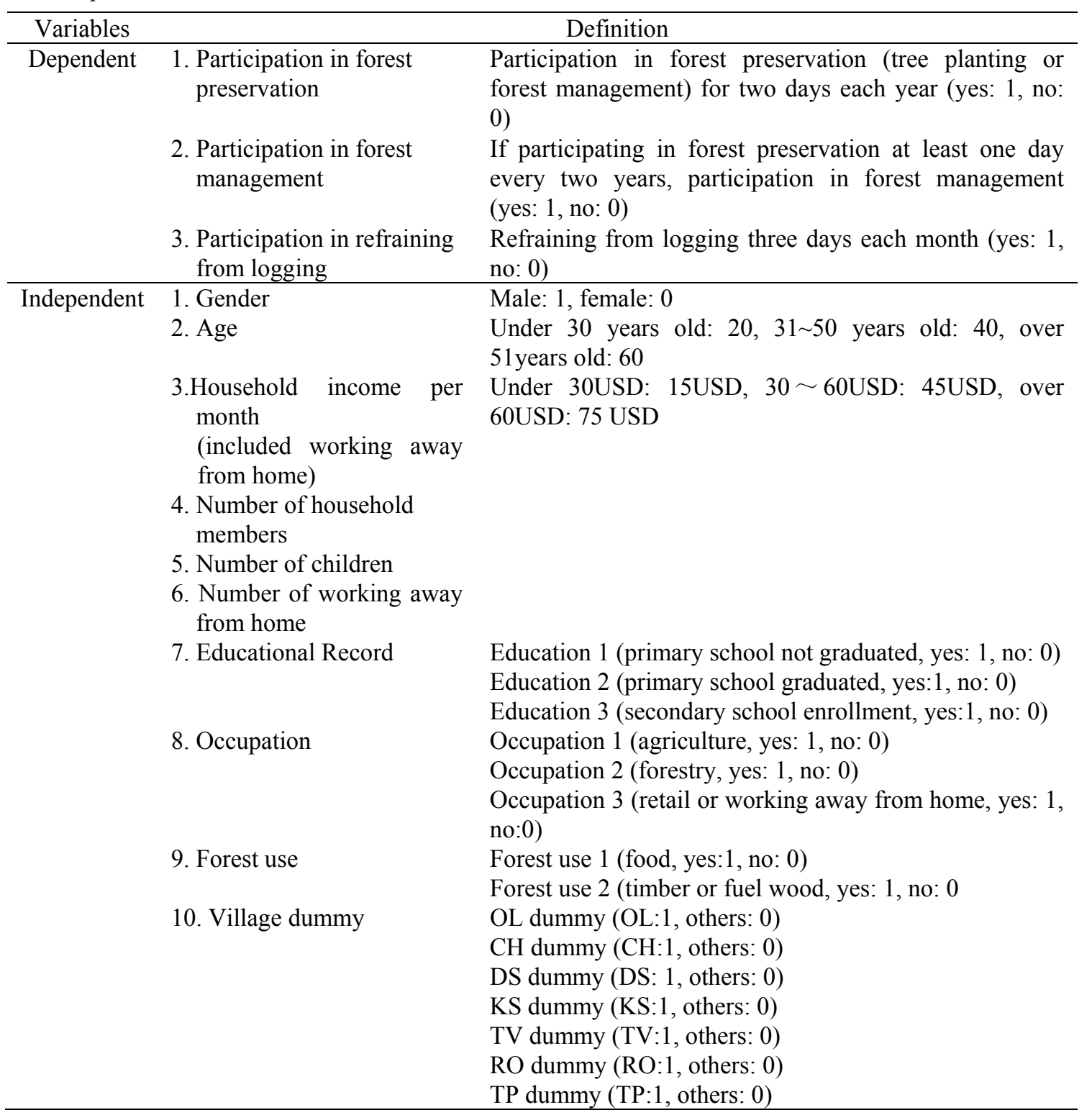


Table 3 shows the basic statistics for the dependent and independent variables 1) socioeconomic attributes of the individual respondents and 2) attributes of the rural village concerned).

Table 3. Basic statistics

\begin{tabular}{|c|c|c|c|c|c|}
\hline Variables & Obs. & Mean & S.D. & Min & Max \\
\hline Participation in forest preservation & 233 & 0.78 & 0.4 & 0 & 1 \\
\hline Participation in forest management & 233 & 0.44 & 0.4 & 0 & 1 \\
\hline Participation in refraining from logging & 231 & 0.57 & 0.5 & 0 & 1 \\
\hline Gender & 233 & 0.32 & 0.5 & 0 & 1 \\
\hline Age & 233 & 42.3 & 15 & 20 & 60 \\
\hline Household income (USD per month) & 232 & 42.9 & 28 & 15 & 75 \\
\hline Number of household members & 232 & 4.89 & 1.7 & 1 & 11 \\
\hline Number of children & 232 & 2.90 & 1.7 & 0 & 9 \\
\hline Number of working away from home & 233 & 0.26 & 0.4 & 0 & 1 \\
\hline $\begin{array}{lllll}\text { Education } & 1 & \text { (primary } & \text { school not } \\
\text { graduated) } & & & & \end{array}$ & 226 & 0.82 & 0.4 & 0 & 1 \\
\hline $\begin{array}{llll}\begin{array}{l}\text { Education } \\
\text { graduated) }\end{array} & 2 & \text { (primary } & \text { school } \\
& & \end{array}$ & 228 & 0.04 & 0.2 & 0 & 1 \\
\hline 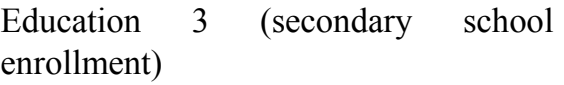 & 222 & 0.14 & 0.3 & 0 & 1 \\
\hline Occupation 1 (agriculture) & 233 & 0.97 & 0.2 & 0 & 1 \\
\hline Occupation 2 (forestry) & 233 & 0.76 & 0.4 & 0 & 1 \\
\hline Occupation 3 (retail etc.) & 233 & 0.57 & 0.6 & 0 & 1 \\
\hline Forest use 1 (food) & 183 & 0.51 & 0.5 & 0 & 1 \\
\hline Forest use 2 (timber etc.) & 233 & 0.09 & 0.3 & 0 & 1 \\
\hline OL & 233 & 0.13 & 0.3 & 0 & 1 \\
\hline $\mathrm{CH}$ & 233 & 0.23 & 0.4 & 0 & 1 \\
\hline DS & 233 & 0.14 & 0.3 & 0 & 1 \\
\hline KS & 233 & 0.26 & 0.4 & 0 & 1 \\
\hline TV & 233 & 0.09 & 0.3 & 0 & 1 \\
\hline RO & 233 & 0.13 & 0.3 & 0 & 1 \\
\hline KP & 233 & 0.03 & 0.2 & 0 & 1 \\
\hline
\end{tabular}

\subsection{Model}

The function for participation in forest preservation activity is determined by 1) the socioeconomic attributes of the individual respondent and 2) attributes of the rural village concerned, and is calculated by equation (1), below.

$$
\operatorname{Pr}\left(Y_{i}=1\right)=f\left(X_{i}, V_{i}\right)
$$

$Y_{i}$ represents the forest preservation activity (tree planting, forest management, refraining from logging), $X_{i}$ is the vector showing relevant socioeconomic attributes, and $V_{i}$ is the vector showing the attributes of the rural village concerned.

Below, as in equation (2), function $f(\cdot)$ gives the logistic distribution function.

$$
\operatorname{Pr}\left(Y_{i}=1\right)=\frac{\exp \left(\beta_{0}+\beta_{1} X_{i}+\beta_{2} V_{i}\right)}{\left(1+\exp \left(\beta_{0}+\beta_{1} X_{i}+\beta_{2} V_{i}\right)\right)}
$$

$\beta_{0}$ to $\beta_{2}$ are the unknown parameters (constant and coefficient vectors).

\section{Results}

Table 4 shows the results of logit analysis estimations. 
Table 4. Estimation results

\begin{tabular}{|c|c|c|c|c|c|c|}
\hline & \multicolumn{2}{|c|}{ Forest preservation } & \multicolumn{2}{|c|}{ Forest management } & \multicolumn{2}{|c|}{ Refraining from logging } \\
\hline & $\begin{array}{c}\text { Model } 1 \\
\text { coefficient }\end{array}$ & $\begin{array}{c}\text { Model } 2 \\
\text { coefficient }\end{array}$ & $\begin{array}{c}\text { Model } 3 \\
\text { coefficient }\end{array}$ & $\begin{array}{c}\text { Model } 4 \\
\text { coefficient }\end{array}$ & $\begin{array}{l}\text { Model } 5 \\
\text { coefficient }\end{array}$ & $\begin{array}{c}\text { Model } 6 \\
\text { coefficient }\end{array}$ \\
\hline Gender (male) & $\begin{array}{l}0.9865 * \\
(0.5486)\end{array}$ & $\begin{array}{l}1.0254 * \\
(0.5385)\end{array}$ & $\begin{array}{c}0.3935 \\
(0.3709)\end{array}$ & $\begin{array}{c}0.2201 \\
(0.3003)\end{array}$ & $\begin{array}{l}-0.4108 \\
(0.4024)\end{array}$ & \\
\hline Age & $\begin{array}{c}-0.0546^{* * *} \\
(0.0196)\end{array}$ & $\begin{array}{c}-0.0599 * * * \\
(0.0184)\end{array}$ & $\begin{array}{c}0.0095 \\
(0.0127)\end{array}$ & & $\begin{array}{c}0.0137 \\
(0.0139)\end{array}$ & \\
\hline Household income & $\begin{array}{c}0.0040 \\
(0.0105)\end{array}$ & & $\begin{array}{c}0.0067 \\
(0.0074)\end{array}$ & & $\begin{array}{l}-0.0207 * * \\
(0.0082)\end{array}$ & $\begin{array}{c}-0.0236^{* * *} \\
(0.0068)\end{array}$ \\
\hline $\begin{array}{l}\text { Number of household } \\
\text { Members }\end{array}$ & $\begin{array}{l}0.9113 * \\
(0.4830)\end{array}$ & $\begin{array}{l}0.8718 * \\
(0.4518)\end{array}$ & $\begin{array}{c}0.3841 \\
(0.2615)\end{array}$ & $\begin{array}{l}0.4917 * * \\
(0.2207)\end{array}$ & $\begin{array}{l}-0.1008 \\
(0.2961)\end{array}$ & \\
\hline Number of children & $\begin{array}{l}-0.9275^{*} \\
(0.5092)\end{array}$ & $\begin{array}{l}-0.9270^{*} \\
(0.4808)\end{array}$ & $\begin{array}{l}-0.3606 \\
(0.2743)\end{array}$ & $\begin{array}{l}-0.3972 * \\
(0.2247)\end{array}$ & $\begin{array}{c}0.5205 \\
(0.3205)\end{array}$ & $\begin{array}{c}0.4667 * * * \\
(0.1330)\end{array}$ \\
\hline $\begin{array}{l}\text { Number of working } \\
\text { away from home }\end{array}$ & $\begin{array}{l}-0.3403 \\
(0.2956)\end{array}$ & & $\begin{array}{c}0.0319 \\
(0.2424)\end{array}$ & & $\begin{array}{c}0.2963 \\
(0.3777)\end{array}$ & \\
\hline $\begin{array}{l}\text { Education } 2 \text { (primary } \\
\text { school graduated) }\end{array}$ & $\begin{array}{c}-2.7083^{* *} \\
(1.1968)\end{array}$ & $\begin{array}{c}-2.6092 * * \\
(1.1259)\end{array}$ & $\begin{array}{l}-0.8933 \\
(1.0029)\end{array}$ & & $\begin{array}{l}-0.7532 \\
(1.1323)\end{array}$ & \\
\hline $\begin{array}{l}\text { Education } 3 \text { (secondary } \\
\text { shool enrollment) }\end{array}$ & $\begin{array}{c}0.3020 \\
(0.8851)\end{array}$ & & $\begin{array}{c}0.2713 \\
(0.5283)\end{array}$ & & $\begin{array}{c}0.3978 \\
(0.5878)\end{array}$ & \\
\hline $\begin{array}{l}\text { Occupation } 1 \\
\text { (agriculture) }\end{array}$ & $\begin{array}{l}3.4445 * * \\
(1.4980)\end{array}$ & $\begin{array}{l}3.0698 * * \\
(1.3031)\end{array}$ & $\begin{array}{l}-1.4008 \\
(1.1215)\end{array}$ & & $\begin{array}{c}0.3978 \\
(1.1500)\end{array}$ & $\begin{array}{l}-1.1817 \\
(1.0551)\end{array}$ \\
\hline $\begin{array}{l}\text { Occupation } 2 \\
\text { (forestry) }\end{array}$ & $\begin{array}{l}1.4626 * * \\
(0.7291)\end{array}$ & $\begin{array}{l}1.3446^{* *} \\
(0.6285)\end{array}$ & $\begin{array}{c}0.6513 \\
(0.5884)\end{array}$ & & $\begin{array}{l}-1.3391 * * \\
(0.6261)\end{array}$ & $\begin{array}{c}-1.2630 * * \\
(0.5022)\end{array}$ \\
\hline $\begin{array}{l}\text { Occupation } 3 \\
\text { (retail etc.) }\end{array}$ & $\begin{array}{l}1.8615 * * * \\
(0.6228)\end{array}$ & $\begin{array}{c}1.6900 * * * \\
(0.5003)\end{array}$ & $\begin{array}{c}0.4111 \\
(0.3379)\end{array}$ & $\begin{array}{c}0.3481 \\
(0.2314)\end{array}$ & $\begin{array}{l}-0.2076 \\
(0.3960)\end{array}$ & \\
\hline $\begin{array}{l}\text { Forest use } 1 \\
\text { (food) }\end{array}$ & $\begin{array}{l}-0.6695 \\
(0.4986)\end{array}$ & $\begin{array}{l}-0.8018^{*} \\
(0.4768)\end{array}$ & $\begin{array}{l}-0.4736 \\
(0.3692)\end{array}$ & & $\begin{array}{c}0.5829 \\
(0.3919)\end{array}$ & $\begin{array}{l}0.7123 * * \\
(0.3615)\end{array}$ \\
\hline $\begin{array}{l}\text { Forest use } 2 \\
\text { (timber etc.) }\end{array}$ & $\begin{array}{l}-0.2674 \\
(0.7089)\end{array}$ & & $\begin{array}{l}-1.1340 \\
(0.7331)\end{array}$ & $\begin{array}{l}-0.9922^{*} \\
(0.5609)\end{array}$ & $\begin{array}{c}0.5246 \\
(0.6477)\end{array}$ & \\
\hline $\mathrm{CH}$ & $\begin{array}{c}0.0896 \\
(0.8558)\end{array}$ & & $\begin{array}{c}0.3133 \\
(0.6128)\end{array}$ & & $\begin{array}{l}-1.1429 * \\
(0.6432)\end{array}$ & $\begin{array}{c}-1.3451 * * * \\
(0.4188)\end{array}$ \\
\hline DS & $\begin{array}{l}2.3210^{*} \\
(1.1154)\end{array}$ & $\begin{array}{l}2.1817 * * \\
(1.0300)\end{array}$ & $\begin{array}{l}2.0973 * \\
(0.7909)\end{array}$ & $\begin{array}{l}0.7984 * \\
(0.4169)\end{array}$ & $\begin{array}{c}0.5848 \\
(0.9474)\end{array}$ & \\
\hline $\mathrm{KS}$ & $\begin{array}{l}-0.0719 \\
(0.8168)\end{array}$ & & $\begin{array}{c}0.3438 \\
(0.5722)\end{array}$ & & $\begin{array}{c}0.4750 \\
(0.5921)\end{array}$ & \\
\hline TV & $\begin{array}{l}-1.1163 \\
(0.8489)\end{array}$ & $\begin{array}{l}-1.1121^{*} \\
(0.6669)\end{array}$ & $\begin{array}{c}-0.5768 \\
(0.7067)\end{array}$ & $\begin{array}{l}-0.9452 * \\
(0.5480)\end{array}$ & $\begin{array}{c}0.1829 \\
(0.7712)\end{array}$ & \\
\hline $\mathrm{TP}$ & $\begin{array}{l}-1.9281 \\
(1.2025)\end{array}$ & $\begin{array}{c}-1.9217 * * \\
(0.9695)\end{array}$ & $\begin{array}{l}-1.0120 \\
(1.1525)\end{array}$ & $\begin{array}{l}-0.6796 \\
(0.8567)\end{array}$ & $\begin{array}{c}0.2212 \\
(1.0002)\end{array}$ & \\
\hline Constant & $\begin{array}{l}-2.9954 \\
(2.4388)\end{array}$ & $\begin{array}{l}-1.9127 \\
(1.9455)\end{array}$ & $\begin{array}{l}-1.4758 \\
(1.7117)\end{array}$ & $\begin{array}{c}-1.7040 * * * \\
(0.5752)\end{array}$ & $\begin{array}{c}1.8313 \\
(1.7969)\end{array}$ & $\begin{array}{l}2.2404^{*} \\
(1.2778)\end{array}$ \\
\hline Obs. & 176 & 177 & 176 & 232 & 174 & 179 \\
\hline McFadden R-squared & 0.2984 & 0.2913 & 0.1052 & 0.0630 & 0.2353 & 0.2137 \\
\hline Log likelihood & -66.177 & -67.030 & -106.53 & -149.089 & -91.506 & -96.382 \\
\hline
\end{tabular}

Note. In the village dummy, OL is reference village. RO is excluded from village dummy because of not having forestry use data of food. Significance level based on $p$ value represents $* * * 1 \%, * * 5 \%, * 10 \%$. The value in parentheses is the Standard Error. 


\subsection{Participation in "Forest Preservation" ("Tree Planting or Forest Management")}

Let us consider participation in voluntary labor relating to "tree planting or forest management." Model 1 is estimated using all independent variables, while Model 2 is estimated with a focus on significant independent variables.

Looking at Model 1, for participation in "tree planting or forest management," significant variables are gender, age, number of household members, number of children, level of education 2 (primary school graduated), occupation 1 (agriculture), occupation 2 (forestry), occupation 3 (retail, working away from home), and Village DS.

Coefficients for gender, number of household members, occupation 1 (agriculture), occupation 2 (forestry), and occupation 3 (retail, working away from home), and the Village DS dummy variable have positive values. Therefore, the following relationships are obtained. Men are more likely to participate than women, and a high number of household members is associated with a high participation rate. There is a high rate of participation among those who work in agriculture, forestry, retail, or away from home. The rate of participation is high in Village DS compared to Village OL, the reference village.

Coefficients for age, number of children, and education 2 (primary school graduated) have significant negative values. Advanced age is associated with a low participation rate. In addition, a high number of children is associated with a low participation rate. It is possible that, when a household has young children, it will be difficult to participate due to caring responsibilities. The "education 2" variable refers to graduation from primary school and, as many of the respondents did not graduate primary school, participation by primary school graduates is low. In this area, school education is not a significant factor driving participation in forest preservation.

Model 2 is an estimation focusing on the variables revealed as significant in Model 1. All variables in Model 1 were significant, with no change in positive or negative sign. New significant variables emerged in Model 2. First is use of the forest for food (the "forest use 1" variable). Its coefficient is negative, meaning that respondents who used the forest for food have low participation in forest preservation. Second, looking at the dummy variables for the various rural villages, coefficients for Village TV and Village TP are negative, meaning that participation in forest preservation in those villages is lower than in the reference village, Village OL.

\subsection{Participation in Forest Management}

Regarding participation in forest management, Model 3 shows that the only significant variable is the dummy variable for Village DS. As already shown, residents in all villages have a positive attitude to participation in "tree planting or forest management," but they are not so positive about forest management specifically. Only in Village DS is the rate of participation significantly higher than that in reference village, Village OL, for both "tree planting or forest management" and forest management.

Model 4 is an estimation excluding the independent variables that were not significant in Model 3 one by one. In Model 4, the significant variables are number of household members, number of children, forest use 2 (timber), and the dummy variables for Village DS and Village TV. A high number of household members is associated with a high level of participation in forest management, and an increase in the number of children reduces the rate of participation. Use of the forest for timber reduces participation in forest management. The Village DS dummy variable is associated with a high participation rate and that for Village TV with a low participation rate.

\subsection{Refraining from Logging}

Model 5 is an estimation using all independent variables. The significant variables are household income, occupation 2 (forestry), and the dummy variable for Village $\mathrm{CH}$. The factors that impact refraining from logging are different from those that impact "tree planting or forest management."

Household income has a negative coefficient and income expansion therefore reduces refraining from logging. Occupation 2 refers to working in forestry. Its coefficient is also negative, and working in forestry therefore reduces refraining from logging. This is likely to be a reflection of the fact that refraining from logging is contrary to the economic benefit of those working in forestry. The coefficient for the dummy variable for Village $\mathrm{CH}$ is negative, implying that Village $\mathrm{CH}$ has a negative attitude to refraining from logging. The proportion of residents of Village $\mathrm{CH}$ engaged in forestry is high, at $90.6 \%$, and refraining from logging is the lowest among all the villages, at $35.8 \%$.

Model 6 is an estimation excluding the independent variables that were not significant in Model 5 one by one. Using Model 6, the variables that were significant in Model 5 remained significant and, in addition, number of 
children and forest use 1 (food) were significant variables. The coefficient for number of children is positive and when the number of children is higher, refraining from logging increases. Use of the forest for food also increases refraining from logging.

\section{Discussion}

\subsection{Differences according to the Nature of the Activity}

Factors impacting participation in forest preservation activity differ according to the nature of the activity, that is, whether it is "tree-planting or forest management," forest management, or refraining from logging.

First, 1) gender and 2) age impact "tree planting or forest management," but do not impact forest management and refraining from logging. Participation in "tree planting or forest management" is higher for male (Note 5) and for younger people. 3) The number of household members has a positive impact on "tree-planting or forest management" and on forest management but has no impact on refraining from logging. 4) A high number of children is associated with low participation in "tree-planting or forest management" and forest management but with high levels of refraining from logging.

Second, 5) household income has no impact on "tree-planting or forest management" and on forest management but has a negative impact on refraining from logging. A high household income is associated with low refraining from logging. 6) Education level has a negative impact on "tree-planting or forest management" and no impact on forest management or refraining from logging. Participation in forest preservation by those who graduated from primary school is lower than that by those who did not finish primary school. 7) Working in agriculture has a positive effect on participation in "tree-planting or forest management," but no impact on forest management or refraining from logging. Working in forestry raises participation in "tree-planting or forest management," but lowers refraining from logging. When 8) the purpose of forest use is to find food, participation in "tree-planting or forest management" is reduced but refraining from logging is raised. Use of the forest for timber has no impact on refraining from logging but reduces participation in forest management.

Third, with regards to the village dummy variables, it was found that there is a significant impact for Villages $\mathrm{CH}$, DS, TV, and TP compared to that for Village OL. For Village $\mathrm{CH}$, refraining from logging is low and participation in "tree-planting or forest management" is low for Village TP. Participation in "tree-planting or forest management" and in forest management is high for Village DS. In contrast, participation in "tree-planting or forest management" and in forest management is low for Village TV.

\subsection{Discrepancy with Previous Research}

The factors impacting participation in forest preservation activity are compared with those in previous studies.

First, regarding household income, Linde-Rahr (2008), Yoeu et al. (2010), and Amiri et al. (2015) found that high household income is associated with high WTP. Muranaka and Terawaki (2005) also found that high household income is associated with a high level of participation in voluntary work (WTW). The results in this article differ from those in these previous studies. Household income has no impact on "tree-planting or forest management" or on forest management. However, high household income is associated with low refraining from logging. In rural villages where many residents live below the poverty line, difference in household income does not cause difference in the rate of participation in environmental protection. However, where households rely on forestry for their income, refraining from logging is reduced.

Second, regarding level of education, Linde-Rahr (2008), Luangmany et al. (2009), and Amiri et al. (2015) found that a high education level was associated with high WTP. The results of this article differ from those of these previous studies. Participation in forest preservation is lower for those who graduated from primary school than for those who did not finish primary school. Level of education has no impact on participation in forest management and refraining from logging. Difference in the level of primary education is not associated with any great difference in terms of forest preservation activity.

Third, regarding understanding of environmental protection issues, Muranaka and Terawaki (2005), Stone et al. (2008), and Yoeu et al. (2010) found that understanding of environmental protection and the local area was associated with high WTP and WTW. In the area surveyed, schools do not necessarily provide adequate environmental education. However, the close-to- $80 \%$ rate of participation in forest preservation could be attributable to continuous engagement in the area by the NGO Japan International Volunteer Center in environmental education and tree-planting activities.

\section{Conclusion}

In this article, empirical analysis was conducted based on observed data regarding participation in forest 
preservation activity in rural villages in the Siem Reap Province in Cambodia. The main conclusions of this article are outlined below.

First, participation by local residents in forest preservation activity differs according to the nature of the activity (i.e., whether it is tree-planting, forest management, or refraining from logging). Almost $80 \%$ of local residents are positive about participation in "forest preservation" (defined as "tree-planting or forest management"), but participation specifically in forest management falls to just over $40 \%$. The rate refraining from logging is slightly below $60 \%$.

Second, participation in forest preservation activity differs according to the socioeconomic attributes of the local residents. 1) Factors that raise the rate of participation in "tree planting or forest management" include being male, having a high number of household members, and working in agriculture, forestry, or retail, or working away from home. On the other hand, factors which reduce the participation rate are being older, having many children, graduating from primary school, and relying on the forest for food. 2) The rate of participation in forest management is raised by having a high number of household members. On the other hand, the rate of participation is reduced by factors such as having many children or relying on the forest for timber. 3) Factors which raise the rate of refraining from logging include having many children and relying on the forest for food, while the rate is reduced by expansion in household income and working in forestry.

Third, unlike in previous studies, it was found that household income and the level of education are not necessarily significant factors in participation in forest preservation activity. For example, expansion in household income has a negative impact on refraining from logging, and a rise in the level of education suppresses participation in "tree-planting or forest management." However, as in previous research, the article implies that an increase in understanding of environmental protection issues promotes forest preservation activity.

\section{Acknowledgment}

The author would like to thank the Japan International Volunteer Center for its invaluable assistance during the survey in Cambodia.

\section{References}

Adams, W., \& Hutton, J. (2007). People, Parks and Poverty: Political Ecology and Biodiversity Conservation. Conservation and Society, 5, 147-183. Retrieved from http://www.conservationandsociety.org/text.asp?2007/5/2/147/49228

Amiri, N., Emadian, S. F., Fallah, A., Adeli, K., \& Amirnejad, H. (2015). Estimation of Conservation Value of Myrtle (Myrtus Communis) Using a Contingent Valuation Method: A Case Study in a Dooreh Forest Area, Lorestan Province, Iran. Forest Ecosystems, 2(30), 1-11. https://doi.org/10.1186/s40663-015-0051-6

Brugnaro, C. (2010). Valuing Riparian Forests Restoration: A CVM Application in Corumbatai River Basin. Revista de Economia e Sociologia Rural, 48(3), 507-520. http://dx.doi.org/10.1590/S0103-20032010000300001

Chaudhry, P., Singh, B., \& Tewari, V. P. (2007). Non-market Economic Valuation in Developing Countries: Role of Participant Observation Method in CVM Analysis. Journal of Forest Economics, 11, 259-275. https://doi.org/10.1016/j.jfe.2006.12.001

Clements, T., \& Milner-Gulland, E. (2015). Impact of Payments for Environmental Services and Protected Areas on Local Livelihoods and Forest Conservation in Northern Cambodia. Conservation Biology, 29(1), 78-87. https://doi.org/10.1111/cobi.12423

Clements, T., Suon, S., Wilkie, D., \& Milner-Gulland, E. J. (2014). Impacts of Protected Areas on Local $\begin{array}{llll}\text { Livelihoods in Cambodia. World } & \text { Development, }\end{array}$ https://doi.org/10.1016/j.worlddev.2014.03.008

Duncan, B. (1999). Modeling Charitable Contribution of Time and Money. Journal of Public Economics, 72 , 213-241. https://doi.org/10.1016/S0047-2727(98)00097-8

Echessah, P. N., Swallow, B. M., Kamara, D. W., \& Curry, J. J. (1997). Willingness to Contribute Labor and Money to Tsetse Control: Application of Contingent Valuation in Busia Direct, Kenya. World Development, 25(2), 239-253. https://doi.org/10.1016/S0305-750X(96)00095-2

Ehara, M., Hyakumura, K., Nomura, H., Matsuura, T., Sokh, H., \& Leng, C. (2016). Identifying Characteristics of Households Affected by Deforestation in Their Fuelwood and Non-timber Forest Product Collections: 
Case Study in Kampong Thom Province, Cambodia. Land Use Policy, 52, 93-102. https://doi.org/10.1016/j.landusepol.2015.12.006

Kim, S., Sasaki, N., \& Koike, M. (2008). Assessment of Non-timber Forest Products in Phnom Kok Community Forest, Cambodia. Asia Europe Journal, 6(2), 345-354. https://ink.springer.com/article/10.1007/s10308-008-0180-4

Linde-Rahr, M. (2008). Willingness to Pay for Forest Property Rights and the Value of Increased Property Rights Security. Environmental and Resource Economics, 41(4), 465-478.

Luangmany, D., Voravong, S., Thanthathep, K. K., Souphonphacdy, D., \& Baylatry, M. (2009) Valuing Environmental Services Using Contingent Valuation Method. Singapore: Economy and Environmental $\begin{array}{lllll}\text { Program for } & \text { Southeast } & \text { Asia. } & \text { Retrieved }\end{array}$ http://econ.nida.ac.th/attachments/article/1932/Paper\%202\%20Lao-Environmental\%20Services.pdf

Ministry of Environment, Cambodia. (2003). Cambodia National Report on Protected Areas and Development, Queensland: ICEM, Indooroopilly. Retrieved http://www.mekong-protected-areas.org/cambodia/docs/Cambodia_nr.pdf

Ministry of Planning, Cambodia. (2003). The Cambodia Millennium Development Goals Report. Phnom Penh: Ministry of Planning. http://planipolis.iiep.unesco.org/sites/planipolis/files/ressources/cambodia_mdg_report_2003.pdf

Ministry of Planning, Cambodia. (2011). Achieving Cambodia's Millennium Development Goals: Update 2010, Phnom Penh: Ministry of Planning. Retrieved from http://www.mop.gov.kh/DocumentEN/CMDG\%202011\%20Report.pdf

Ministry of Planning, Cambodia. (2014). Annual Progress Report 2013: Achieving Cambodia's Millennium Development Goals, Phnom Penh: Ministry of Planning. Retrieved from https://policy.asiapacificenergy.org/sites/default/files/CMDG\%20Annual\%20Progress\%20Report\%202013 $\% 20$ En_Final.pdf

Muranaka, A., \& Terawaki, T. (2005). Hyoumei senkoushakudo ni kizuita satoyama kanri no shakai keizai hyouka: Hyogo-ken nakachou okunaka 'kannon no mori' shuuhen juumin no shiharai ishi gaku to roudou ishi ryou ni chakumoku shite (Socioeconomic Evaluation for Benefits of Satoyama Forest Management by Stated Preference Measures Analysis of Willingness to Pay and Willingness to Work from Inhabitants around the Kannon Forest in Okunaka Hamlet, Naka Town Hyogo Prefecture, Japan). Japanese Journal of Human Geography, 57(2), 27-46. https://doi.org/10.4200/jjhg1948.57.153

Open Development Cambodia. (2015). Hectare Forest Cover by Province in Cambodia (1973 - 2014). Retrieved from https://data.opendevelopmentmekong.net/dataset/hectare-forest-cover-by-province-in-cambodia-1973-2014

Open Development Cambodia. (2016). Forest Cover. Retrieved from https://opendevelopmentcambodia.net/profiles/forest-cover/

Stone, K., Bhat, M., Bhatta, R., \& Mathews, A. (2008). Factors Influencing Community Participation in Mangroves Restoring: A Contingent Valuation Analysis. Ocean \& Coastal Management, 51, 476-484. https://doi.org/10.1016/j.ocecoaman.2008.02.001

Yoeu, A., \& Pabuayon, I. M. (2011). Willingness to Pay for the Conservation of Flooded Forest in the Tonle Sap Biosphere Reserve, Cambodia. International Journal of Environmental and Rural Development, 2(2), 1-5. Retrieved from http://iserd.net/ijerd22/22001.pdf

\section{Notes}

Note 1. Although the establishment of protected areas is effective in forest preservation, it can exacerbate the poverty of local residents who depend on the forest (Adams and Hutton, 2007). Studies by Clements et al. (2014) and by Clements and Milner-Gulland (2015) relating to the impact of Cambodia's protected areas on the poverty and lives of rural communities did not confirm a deterioration in poverty or reduction in crop levels.

Note 2. Ehara et al. (2016) investigated the impact of forest reduction in Kampong Thom Province on the production and gathering of fuel wood and non-wood forest products by rural communities and found that the impact varied from community to community.

Note 3. Chaudhry et al. (2007) investigated CVM in developing countries. Regarding to economic discussion of 
CVM, reference was made to Duncan (1999).

Note 4. In the forests of Cambodia, in addition to timber and fuel wood, local residents harvest other items such as food, animal feed, medicinal herbs for use in traditional healing, cosmetics ingredients, and sap and resin. Kim et al. (2008) conducted case studies relating to non-wood forest products in Cambodia's community forestries.

Note 5. The difference in WTP and WTW according to gender is not limited to forest preservation. Echessah, et al. (1997) report that, regarding participation in prevention of Trypanosoma infection in Kenya, WTP was significant for women and WTW for men.

\section{Copyrights}

Copyright for this article is retained by the author(s), with first publication rights granted to the journal.

This is an open-access article distributed under the terms and conditions of the Creative Commons Attribution license (http://creativecommons.org/licenses/by/4.0/). 